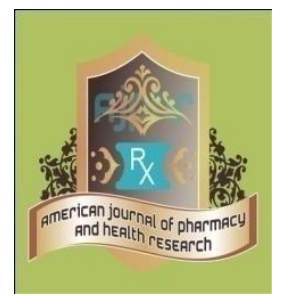

\title{
Assessment of Knowledge, Attitude and Practice Towards Covid 19 among Public
}

\author{
Binu Mathew ${ }^{1}$, Jeeva Jose ${ }^{2}$, Praveena Ponnachan ${ }^{3}$, Doddayya $\mathbf{H}^{4}$ \\ Department of Pharmacy Practice, NET Pharmacy College, Raichur-584103 Karnataka, India.
}

\begin{abstract}
India has taken stringent preventive measures against COVID-19 to control its spread, safeguard citizens and ensure well-being. Public adherence to preventive measures is influenced by their knowledge and attitude toward COVID-19. This study aims to access the knowledge, attitudes, and practices of the public towards COVID-19. A cross-sectional study was contacted in 50 participants using an online self-reported questionnaire. The demographics, knowledge, attitude, and practice of the participants were investigated, and the scores were calculated. The majority of the study participants were knowledgeable about COVID-19, 100\% were aware of the clinical symptoms, and $94 \%$ knew that there is no clinically approved treatment. It was also evident $40 \%$ had low knowledge about wearing masks to prevent infection. Concerning attitudes, participants showed a positive and optimistic attitude toward COVID-19. 40\% concur that the virus can be successfully controlled. But 34\% are not convinced that the government will control this pandemic. Good knowledge of COVID-19 translates into good and safe practices, which suggests that the practices of residents are very cautious. Almost $88 \%$ of respondents refrained from attending social events, $82 \%$ avoided crowded places, and $94 \%$ avoided shaking hands. We also found that young adults are likely to have better knowledge and practices, than older adult people. The majority of the participants had good knowledge, positive attitude, and sufficient practice. Our finding suggests that targeted health interventions should be directed to this particular vulnerable population, who may be at increased risk of contracting COVID-19.
\end{abstract}

Keywords: Knowledge; Awareness; Practice; Novel coronavirus; COVID 19 


\section{INTRODUCTION}

Coronavirus disease 2019 (COVID-19) is defined as an illness caused by a novel coronavirus, now called Severe Acute Respiratory Syndrome Coronavirus 2 (SARS-CoV-2; formerly called 2019-nCoV). COVID-19 is an emerging respiratory infection that was first discovered in December 2019, in Wuhan city, Hubei Province, China. ${ }^{1}$ COVID 19 found in China is genetically closely related to the SARS-CoV-1 virus which caused thousands of deaths in $2002 .^{2}$ SARS-CoV-2 belongs to the larger family of ribonucleic acid (RNA) viruses, leading to infections, from the common cold, to more serious diseases, such as Middle East Respiratory Syndrome (MERS-CoV) and Severe Acute Respiratory Syndrome (SARS-CoV). ${ }^{3}$ The main symptoms of COVID-19 have been identified as fever, dry cough, fatigue, myalgia, shortness of breath, and dyspnoea. ${ }^{4,5}$ More serious cases develop severe pneumonia, acute respiratory distress syndrome, sepsis and septic shock that can lead to death. ${ }^{6}$

COVID-19 is characterized by rapid transmission, and can occur by close contact with an infected person $^{7-11 .}$ There is no vaccine and no specific treatment so far, because it is a new virus and no prior immunity so, entire human population is potentially susceptible to COVID-19 infection. ${ }^{12}$ There is not enough epidemiological information at this time to determine how easily the virus spreads between people, but it is currently estimated that, on average, one infected person will infect two and three more. ${ }^{13}$ COVID-19 has spread widely and rapidly, from Wuhan city, to other parts of the world, threatening the lives of many people. ${ }^{14}$ The incubation period for COVID-19 is estimated at between 2-14 days. At this stage, we know that the virus can be transmitted when people who are infected show flu like symptoms which ranges from a mild upper respiratory illness to rapidly progressive pneumonia and multi-organ failure. ${ }^{15}$ People who are at greater risk are: elderly people and those with health disorders such as HTN, diabetes, CVDs, chronic respiratory disease and cancer. Disease in children appears to be relatively rare and mild. ${ }^{16}$ There is no published evidence yet on the severity of illness among pregnant women after COVID. ${ }^{17}$ ECDC will continue to monitor the emerging scientific literature on this question, and suggests that all pregnant women follow the same precautions for the prevention of COVID-19. ${ }^{18}$ There is no specific treatment for this disease, so healthcare providers treat the clinical symptoms of patients. Supportive care (e.g. fluid management, oxygen therapy, etc.) are effective for patients. ${ }^{19}$

India reported its first COVID-19 case on January 30, 2020 and numbers began to rise in late March 2020, (“Johns Hopkins Coronavirus Resource Center,” 2020) albeit at a low rate, which may be attributed to several government policies including stopping all international flights and 
implementing a nation-wide lockdown at an early stage of the pandemic. By early April 2020, country officials had identified several areas as hotspots of COVID-19 infections in the country and announced an initial 3-week lockdown period on March 24, now extended until May 3. The extension of the initial lockdown period poses further challenges to the already distressed population and to ensuring strict compliance with social distancing guidelines. ${ }^{20}$

Implementing personal hygiene and public health behaviors such as hand washing and social distancing to reduce the spread of virus, but it will be challenging to practice these in many cities and rural areas. ${ }^{21}$ Maintain restrictions on large gatherings such us cultural and faith practices e.g., mass prayer gatherings, large weddings and funerals as these may create super-spreading events that accelerate transmission. ${ }^{22}$ This situation may be compounded by the spread of COVID-19 misinformation including unsupported treatments or promotion of ineffective preventive behaviors. ${ }^{23}$ The Indian Ministry of Health and Family Welfare (MOHFW) along with state-level health departments have been providing information on COVID-19 through both subnational communication channels and through a mobile app, Aarogya-Setu.

Following WHO declaration, countries around the globe, including India, have been leaning on response plans to the pandemic. Despite the unprecedented national measures in combating the outbreak, the success or failure of these efforts is largely dependent on public behavior. Adherence is likely to be influenced by the public's knowledge and practice toward COVID-19. Evidence shows that public knowledge is important in tackling pandemics. ${ }^{24,25}$ By assessing public awareness and knowledge about the coronavirus, deeper insights into existing public perception and practices can be gained, thereby helping to identify attributes that influence the public in adopting healthy practices and responsive behavior. ${ }^{26}$ Assessing public knowledge is also important in identifying gaps and strengthening ongoing prevention efforts. ${ }^{27}$ Thus, this study aims to investigate the knowledge and practices of public, toward COVID-19 during the pandemic spike of the COVID-19. Such information provides baseline data for the prevention and control of these diseases through estimation of the impact of previous prevention efforts made by the government and guiding the need for further interventions.

\section{MATERIALS AND METHOD}

\section{Participants and data collection}

This was a cross -sectional questionnaire-based study conducted among the general population of South-India, for a period of three months from May 2020, to July 2020. Participants willing to participate and those age 10 and above are included in the study. Incomplete survey forms and age group less than 10 years are excluded from the study. As we all know, social-distancing is 
the best way of prevention from COVID-19, therefore, instead of conducting a community-based survey, this study collected the data using Google form platform as an online survey, via a selfreported questionnaire, using Google forms. The link of Google form was circulated to respondents, using various social media platforms like What'sApp Group. Respondents were informed that they were free to withdraw at any time, without giving a reason, and that all information and opinions provided were kept confidential. Online informed consents were obtained before proceeding with the questionnaire. Participants self-selected themselves when they choose to answer the questionnaire.

\section{Questionnaire}

A self-reported questionnaire was developed by the authors, according to guidelines for the community of COVID-19, by the Centers for Disease Control and Prevention (CDC). ${ }^{28}$ The questionnaire was conducted in English language. On the first page of the online questionnaire, respondents were clearly informed about the background and objectives of the study. The questionnaire consisted of four primary sections. The first section gathered information on respondents' socio-demographic characteristics, including age, gender, marital status, education level, work status, region of residence. The second section assessed participants' knowledge of COVID-19. This section included 26 items on modes of transmission, clinical symptoms, treatment, risk groups, isolation, prevention and control. These questions were responded on a Yes/No basis with an additional "I don't know" option. The third section assessed participants' attitudes toward COVID-19. For each of six statements, respondents were asked to state their level of agreement, from "strongly disagree," “disagree," "neutral," "agree," or "strongly agree. The final section of the questionnaire assessed the respondents' practices. This section consisted of five questions related to practices and behavior. The data collected from the questionnaire was entered on MS Excel and descriptive statistics was used in the study.

\section{RESULTS AND DISCUSSION}

A total of 50 participants completed the questionnaire. Table 1 shows the social and demographic characteristics of the study participants. In this study out of 50 respondents, $62 \%$ were females and $38 \%$ were males. Maximum number of patients were found in the age groups of 20-29 young adults (72\%), followed by middle aged peoples 50-59 (12\%), 40-49(10\%) and least were found in the age group of 10-19(4\%) and 30-39 (0\%). In this study it is found that $0 \%$ had primary education, $16 \%$ had secondary level of education and $84 \%$ were college graduates. This literacy is related with the level of awareness with greater importance of educational interventions to the public. Table 2 deals with the knowledge of participants towards COVID 19. 
In a total of 50 participants, (100\%) were aware of the clinical symptoms, and $94 \%$ knew that there is no clinically approved treatment for COVID-19. It was also evident that the current general population (40\%) had little knowledge of when and whom wearing masks to prevent infection. Table 3 points the attitude of participants, 64\% Covid 19suggest that washing hands can prevented. Approximately $40 \%$ concur that the virus can be successfully controlled. Table 4 represents the practice of respondents, and found that there is sufficient practice. Almost $88 \%$ of respondents refrained from attending social events, 82\% avoided crowded places, and 94\% avoided shaking hands.

Table 1: Demographics of study participants.

\begin{tabular}{lllcc}
\hline Sr.no & Variables & & N & Percentage \\
\hline 1 & Sex & Male & 19 & 38 \\
& & Female & 31 & 62 \\
2 & Age & $10-19$ & 2 & 4 \\
& & $20-29$ & 36 & 72 \\
& & $30-39$ & 0 & 0 \\
& & $40-49$ & 5 & 10 \\
3 & \multirow{4}{*}{ Education } & $50-59$ & 6 & 12 \\
& & None & 0 & 0 \\
& & Primary & 0 & 0 \\
& & Secondary & 8 & 16 \\
& & College/university & 42 & 84 \\
\hline
\end{tabular}


Table 2: Responses to the questionnaire on COVID-19 knowledge

\begin{tabular}{|c|c|c|c|c|}
\hline \multirow[t]{2}{*}{ Sr.no } & \multirow[t]{2}{*}{ Statements } & \multicolumn{3}{|l|}{$N(\%)$} \\
\hline & & Yes & no & $\begin{array}{l}\text { Don't } \\
\text { know }\end{array}$ \\
\hline 1 & COVID 19 is caused by a virus & $\begin{array}{l}50 \\
(100)\end{array}$ & $\begin{array}{ll}0 \\
(0)\end{array}$ & $\begin{array}{l}0 \\
(0)\end{array}$ \\
\hline 2 & Incubation period of COVID 19 is 5-14 days & $\begin{array}{l}37 \\
(74)\end{array}$ & $\begin{array}{l}1 \\
(2)\end{array}$ & $\begin{array}{l}12 \\
(24)\end{array}$ \\
\hline 3 & $\begin{array}{l}\text { SARS-CoV-2 spreads from person-to-person within close distance of each other (approx. six } \\
\text { feet). }\end{array}$ & $\begin{array}{l}43 \\
(86)\end{array}$ & $\begin{array}{l}3 \\
(6)\end{array}$ & $\begin{array}{l}4 \\
(8)\end{array}$ \\
\hline 4 & $\begin{array}{l}\text { SARS-CoV-2 spread through respiratory droplets, which occur when infected people cough } \\
\text { and sneeze. }\end{array}$ & $\begin{array}{l}49 \\
(98)\end{array}$ & $\begin{array}{l}1 \\
(2)\end{array}$ & $\begin{array}{l}0 \\
(0)\end{array}$ \\
\hline 5 & $\begin{array}{l}\text { SARS-CoV-2 can be contracted by touching a surface or object, on which the virus is attached, } \\
\text { and then touching one's mouth, nose, or, perhaps, eyes. }\end{array}$ & $\begin{array}{l}41 \\
(82)\end{array}$ & $\begin{array}{l}0 \\
(0)\end{array}$ & $\begin{array}{l}9 \\
(18)\end{array}$ \\
\hline 6 & Close contact or eating wild animals causes COVID-19. & $\begin{array}{l}9 \\
(18)\end{array}$ & $\begin{array}{l}19 \\
(38)\end{array}$ & $\begin{array}{l}22 \\
(44)\end{array}$ \\
\hline 7 & $\begin{array}{l}\text { People infected with SARS-CoV-2 cannot transmit the virus to others when a fever is not } \\
\text { present. }\end{array}$ & $\begin{array}{l}6 \\
(12)\end{array}$ & $\begin{array}{l}29 \\
(58)\end{array}$ & $\begin{array}{l}15 \\
(30)\end{array}$ \\
\hline 8 & $\begin{array}{l}\text { The main clinical symptoms of COVID-19 are fever, fatigue, dry cough, myalgia and shortness } \\
\text { of breath. }\end{array}$ & $\begin{array}{l}50 \\
(100)\end{array}$ & $\begin{array}{l}0 \\
(0)\end{array}$ & $\begin{array}{l}0 \\
(0)\end{array}$ \\
\hline 9 & $\begin{array}{l}\text { Unlike the common cold, congestion, runny nose, and sneezing are less common in people } \\
\text { infected with SARS-CoV-2. }\end{array}$ & $\begin{array}{l}26 \\
(52)\end{array}$ & $\begin{array}{l}12 \\
(24)\end{array}$ & $\begin{array}{l}12 \\
(24)\end{array}$ \\
\hline 10 & Antibiotics are an effective treatment for COVID-19. & $\begin{array}{l}11 \\
(22)\end{array}$ & $\begin{array}{l}19 \\
(38)\end{array}$ & $\begin{array}{l}10 \\
(20)\end{array}$ \\
\hline 11 & $\begin{array}{l}\text { Currently, there is no effective cure for COVID-19, but early symptomatic and supportive } \\
\text { treatment can help most patients recover from the diseases. }\end{array}$ & \begin{tabular}{|l|}
47 \\
$(94)$
\end{tabular} & $\begin{array}{l}0 \\
(0)\end{array}$ & $\begin{array}{l}3 \\
(16)\end{array}$ \\
\hline 12 & $\begin{array}{l}\text { Older adults and those with serious chronic illnesses, such as heart or lung disease and } \\
\text { diabetes, are at increased risk of developing more serious complications from COVID- } 19 \text {. }\end{array}$ & $\begin{array}{l}42 \\
(84)\end{array}$ & $\begin{array}{l}0 \\
(0)\end{array}$ & $\begin{array}{l}8 \\
(16)\end{array}$ \\
\hline 13 & $\begin{array}{l}\text { Not all people with COVID-19 have severe cases. Only older adults with chronic illnesses tend } \\
\text { to be more severe. }\end{array}$ & \begin{tabular}{|l|l|}
30 \\
$(60)$
\end{tabular} & $\begin{array}{l}8 \\
(16)\end{array}$ & $\begin{array}{l}12 \\
(24)\end{array}$ \\
\hline 14 & Pregnant women are more susceptible to infections than non-pregnant women. & $\begin{array}{l}18 \\
(36)\end{array}$ & $\begin{array}{l}11 \\
(22)\end{array}$ & $\begin{array}{l}21 \\
(42)\end{array}$ \\
\hline
\end{tabular}




\begin{tabular}{|c|c|c|c|c|}
\hline 15 & Children do not appear to be at higher risk for COVID-19 than adults. & $\begin{array}{l}8 \\
(16)\end{array}$ & $\begin{array}{l}27 \\
(54)\end{array}$ & $\begin{array}{l}15 \\
(30)\end{array}$ \\
\hline 16 & $\begin{array}{l}\text { It is not necessary for children or young people to take precautionary measures to prevent } \\
\text { SARS-CoV-2 transmission. }\end{array}$ & $\begin{array}{l}0 \\
0\end{array}$ & $\begin{array}{l}41 \\
(82)\end{array}$ & $\begin{array}{l}9 \\
(18)\end{array}$ \\
\hline 17 & $\begin{array}{l}\text { After being in a public place, after nose-blowing, coughing or sneezing, people must wash their } \\
\text { hands with soap and water, or use hand sanitizer containing at least } 60 \% \text { alcohol, for at least } 20 \\
\text { seconds. }\end{array}$ & $\begin{array}{l}46 \\
(92)\end{array}$ & $\begin{array}{l}3 \\
(6)\end{array}$ & $\begin{array}{l}1 \\
(2)\end{array}$ \\
\hline 18 & People should avoid touching their eyes, nose, and mouth with unwashed hands. & $\begin{array}{l}47 \\
(94)\end{array}$ & $\begin{array}{l}2 \\
(4)\end{array}$ & $\begin{array}{l}1 \\
(2)\end{array}$ \\
\hline 19 & Ordinary residents can wear general medical masks to prevent the SARS-CoV-2 infection. & $\begin{array}{l}33 \\
(66)\end{array}$ & $\begin{array}{l}4 \\
(8)\end{array}$ & $\begin{array}{l}13 \\
(26)\end{array}$ \\
\hline 20 & $\begin{array}{l}\text { People should only wear a mask if they are infected with the virus, or if they are caring for } \\
\text { someone with suspected SARS-CoV-2 infection. }\end{array}$ & $\begin{array}{l}20 \\
(40)\end{array}$ & $\begin{array}{l}27 \\
(54)\end{array}$ & $\begin{array}{l}3 \\
(6)\end{array}$ \\
\hline 21 & Healthy food and drinking water increase the body's immunity and resistance to COVID- 19. & $\begin{array}{l}40 \\
(80)\end{array}$ & $\begin{array}{l}4 \\
(8)\end{array}$ & $\begin{array}{l}6 \\
(12)\end{array}$ \\
\hline 22 & $\begin{array}{l}\text { Isolation and treatment of people infected with the SARS-CoV-2, are effective ways to reduce } \\
\text { the spread of virus. }\end{array}$ & $\begin{array}{l}48 \\
(96)\end{array}$ & $\begin{array}{l}0 \\
(0)\end{array}$ & $\begin{array}{l}2 \\
(4)\end{array}$ \\
\hline 23 & $\begin{array}{l}\text { People in contact with someone infected with SARS-CoV-2 should be immediately } \\
\text { quarantined, in an appropriate location, for a general observation period of } 14 \text { days. }\end{array}$ & $\begin{array}{l}48 \\
(96)\end{array}$ & $\begin{array}{l}1 \\
(2)\end{array}$ & $\begin{array}{l}1 \\
(2)\end{array}$ \\
\hline 24 & $\begin{array}{l}\text { To prevent transmission of SARS-CoV-2, people must avoid going to crowded places and } \\
\text { avoid taking public transport. }\end{array}$ & $\begin{array}{l}47 \\
(94)\end{array}$ & $\begin{array}{l}3 \\
(6)\end{array}$ & $\begin{array}{l}0 \\
0\end{array}$ \\
\hline 25 & Vitamin $\mathrm{C}$ is important in COVID 19 treatment & $\begin{array}{l}31 \\
(62)\end{array}$ & $\begin{array}{l}1 \\
(2)\end{array}$ & $\begin{array}{l}18 \\
(36)\end{array}$ \\
\hline 26 & Vitamin D is important in COVID 19 treatment & $\begin{array}{l}18 \\
(36)\end{array}$ & $\begin{array}{l}5 \\
(10)\end{array}$ & $\begin{array}{l}27 \\
(54)\end{array}$ \\
\hline
\end{tabular}

Table 3: Responses to attitudinal statements regarding COVID-19

\begin{tabular}{|c|c|c|c|c|c|c|}
\hline \multirow[t]{2}{*}{ Sr.no } & \multirow[t]{2}{*}{ Statement } & \multicolumn{5}{|l|}{$N(\%)$} \\
\hline & & $\begin{array}{l}\text { Strongly } \\
\text { disagree }\end{array}$ & Disagree & Neutral & Agree & $\begin{array}{l}\text { Strongly } \\
\text { agree }\end{array}$ \\
\hline 1 & $\begin{array}{l}\text { It is important to keep my distance from others, to } \\
\text { avoid spreading SARS-CoV-2. }\end{array}$ & $\begin{array}{l}0 \\
(0)\end{array}$ & $\begin{array}{l}5 \\
(10)\end{array}$ & $\begin{array}{l}0 \\
(0)\end{array}$ & $\begin{array}{l}7 \\
(14)\end{array}$ & $\begin{array}{l}8 \\
8 \\
(16)\end{array}$ \\
\hline 2 & Washing hands is essential to protect myself from & 0 & 5 & 0 & 13 & 32 \\
\hline
\end{tabular}




\begin{tabular}{|c|c|c|c|c|c|c|}
\hline & COVID-19. & (0) & (10) & (0) & (26) & (64) \\
\hline 3 & $\begin{array}{l}\text { To protect myself from COVID-19 exposure, I } \\
\text { should stay home if I am sick, unless I am receiving } \\
\text { medical care. }\end{array}$ & $\begin{array}{l}0 \\
(0)\end{array}$ & $\begin{array}{l}5 \\
(10)\end{array}$ & $\begin{array}{l}0 \\
(0)\end{array}$ & $\begin{array}{l}17 \\
(34)\end{array}$ & $\begin{array}{l}28 \\
(56)\end{array}$ \\
\hline 4 & $\begin{array}{l}\text { COVID-19 will eventually be successfully } \\
\text { controlled. }\end{array}$ & $\begin{array}{l}1 \\
(2)\end{array}$ & $\begin{array}{l}9 \\
(18)\end{array}$ & $\begin{array}{l}8 \\
(16)\end{array}$ & $\begin{array}{l}12 \\
(24)\end{array}$ & $\begin{array}{l}20 \\
(40)\end{array}$ \\
\hline 5 & $\begin{array}{l}\text { India's strict measures can help to win the battle } \\
\text { against COVID- } 19 \text {. }\end{array}$ & $\begin{array}{l}1 \\
(2)\end{array}$ & $\begin{array}{l}17 \\
(34)\end{array}$ & $\begin{array}{l}6 \\
(12)\end{array}$ & $\begin{array}{l}10 \\
(2)\end{array}$ & $\begin{array}{l}16 \\
(32)\end{array}$ \\
\hline 6 & $\begin{array}{l}\text { Compliance with the Ministry of Health precautions } \\
\text { will prevent the spread of COVID-19. }\end{array}$ & $\begin{array}{l}5 \\
(10)\end{array}$ & $\begin{array}{l}5 \\
(10)\end{array}$ & $\begin{array}{l}8 \\
(16)\end{array}$ & $\begin{array}{l}12 \\
(24)\end{array}$ & $\begin{array}{l}20 \\
(40)\end{array}$ \\
\hline
\end{tabular}

Table 4: Responses to practices related to COVID-19.

\begin{tabular}{|c|c|c|c|}
\hline \multirow[t]{2}{*}{ Sr.no } & \multirow[t]{2}{*}{ Statement } & \multicolumn{2}{|c|}{$N(\%)$} \\
\hline & & Yes & No \\
\hline 1 & $\begin{array}{l}\text { Have you recently been to a social event involving a } \\
\text { large number of people? }\end{array}$ & $\begin{array}{l}5 \\
(10)\end{array}$ & $\begin{array}{l}44 \\
(88)\end{array}$ \\
\hline 2 & Have you recently been to a crowded place? & $\begin{array}{l}11 \\
(22)\end{array}$ & $\begin{array}{l}41 \\
(82)\end{array}$ \\
\hline 3 & $\begin{array}{l}\text { Have you recently avoided cultural behaviors, such as } \\
\text { shaking hands? }\end{array}$ & $\begin{array}{l}47 \\
(94)\end{array}$ & $\begin{array}{l}3 \\
(6)\end{array}$ \\
\hline 4 & Have you been practicing social distancing? & $\begin{array}{l}46 \\
(92)\end{array}$ & $\begin{array}{l}4 \\
(8)\end{array}$ \\
\hline 5 & Have you been practicing use of masks? & $\begin{array}{l}48 \\
(96)\end{array}$ & $\begin{array}{l}2 \\
(4)\end{array}$ \\
\hline 6 & $\begin{array}{l}\text { Recently, have you frequently washed your hands with } \\
\text { soap and water, for at least } 40 \text { seconds, especially after } \\
\text { going to a public place, or after nose-blowing, coughing, } \\
\text { or sneezing? }\end{array}$ & $\begin{array}{l}46 \\
(92)\end{array}$ & $\begin{array}{l}4 \\
(8)\end{array}$ \\
\hline
\end{tabular}


Our findings indicate that most study participants were knowledgeable about COVID-19. This finding is consistent with other studies that have shown satisfactory levels of knowledge, across the Indian population, for epidemics, such as MERS. ${ }^{29,30}$ In our study, the high rate of correct answers to knowledge-related questions among participants, was not surprising. This may be due to the characteristics of the sample, as $84 \%$ had a college or university degree. It may also be due to the distribution of the questionnaire, amid the COVID-19 outbreak. In that time, people may have gained awareness and knowledge about the disease and its transmission, via television, news and media platforms, to protect themselves and their families. All the participants in our study $(100 \%)$ were aware of the clinical symptoms, and $94 \%$ knew that there is no clinically approved treatment for COVID-19 as of the date of this manuscript. Viral infections have been documented to be highly contagious among people in close proximity. ${ }^{28}$ However, approximately half of the respondents were unaware that SARS-CoV-2 could spread from person-to person in close proximity. It was also evident that the current general population (40\%) had little knowledge of when and whom wearing masks to prevent infection. According to the WHO and the CDC, faces mask should only be worn by those who are sick or caring for people suspected of having COVID-19. ${ }^{11,28}$ These findings highlight the need to continue to encourage and emphasize maintaining social distancing, as a means of preventing the spread of the virus. It is important to note that there has been a great deal of efforts at all levels by the government, including public awareness campaigns. The MOHFW works with the public and the media, especially via social media platforms. These early actions on engaging the public in prevention and control measures, as well as efforts to combat rumors and misinformation, have been greatly expanded. $^{31}$ This experience has helped the government in taking prompt response and precautionary measures against COVID-19 to control its spread. This finding is supported by other studies that have found that female, and more educated respondents are more knowledgeable about emerging communicable diseases. ${ }^{29}$ Our findings suggest that greater emphasis should be placed on mass media, to target low-educated people, to improve public knowledge on the COVID pandemic, through awareness-raising interventions. Concerning attitudes, participants showed a positive and optimistic attitude toward COVID-19.

Approximately $40 \%$ concur that the virus can be successfully controlled. Most of the participants had confidence that COVID-19 will be eliminated and had a certainty that we can win the fight against the infection. This attitude could have attributed to positive practice with majority reporting not visit crowded places and wore masks whenever they go out of their homes. Furthermore, nearly all reported adhering to preventive measures as instructed by their national 
health care authority. ${ }^{32}$ But $34 \%$ are not convinced that the government will control the pandemic. This implies that the necessity of the government's unprecedented actions and prompt response in taking stringent control and precautionary measures against COVID-19, to safeguard citizens and ensure their well-being. These results contrast with other findings that suggest people tend to express negative emotions, such as anxiety and panic, during a pandemic that could affect their attitude. ${ }^{33}$

Nevertheless, our results show that the participants' high knowledge of COVID-19 translates into good and safe practices, during the COVID-19 pandemic, which suggests that the practices of residents are very cautious. Almost $88 \%$ of respondents refrained from attending social events, $82 \%$ avoided crowded places, and $94 \%$ avoided shaking hands. Even so, there was still a percentage of participants who were not practicing proper hand hygiene and social distancing. Respondents adopted good and safe practices, as a result of education and outreach materials, to increase public understating of the disease, and influence behavioral change. Finally, the study findings may be useful to inform policymakers and healthcare professionals, on further public health interventions, awareness-raising, policies, and health education programs. Our finding suggests that targeted health education interventions should be directed to this particular vulnerable population at high risk of contracting COVID-19.

\section{CONCLUSION}

In summary, the present study was able to provide a comprehensive examination of the knowledge, attitude and practices of public towards COVID-19. The findings suggest that public have an acceptable level of knowledge on COVID-19 and are generally positive in their outlook on overcoming the pandemic. Knowledge of the disease is considered the first stepping stone to any health education activity that is implemented. Knowing the causes and transmission sources of a disease, increases the likelihood that people will become more aware of the spread of communicable diseases, and of the preventive measures to slow transmission. Even so, consistent messaging from the government and/ or health authorities are key to aid public knowledge and understanding of COVID-19. Additionally, some categories of the population may benefit from specific health education programs to raise COVID-19 knowledge and improve practices. The results of this study suggest that more emphasis should be placed on less educated people. The findings may help policymakers identify the target populations, for COVID-19 prevention and health education. People should continue to strengthen knowledge, attitude, and practice towards COVID-19, so that India can win the battle against the disease.

\section{ACKNOWLEDGEMENT}


We express our sincere thanks to Dr. Ashok Mahendrakar, Medical Superintendent, NMCH\&RC, Raichur who had permitted us and provided us with the facilities to execute this work. The authors would like to thank all participants who responded to the invitation to complete the questionnaire for this study.

\section{REFERENCES}

1. Wu F, Zhao S, Yu B, Chen Y-M, Wang W, Song Z-G, et al. A new coronavirus associated with human respiratory disease in China. Nature. (2020) 579:265-9.

2. Mantwill S, Monestel-Umaña S, Schulz PJ (2015) The relationship between health literacy and health disparities: A systematic review. PLoS One. 10: e0145455.

3. Zhou P, Yang X-L, Wang X-G, Hu B, Zhang L, Zhang W, et al. A pneumonia outbreak associated with a new coronavirus of probable bat origin. Nature. (2020) 579:270-3.

4. Riou J, Althaus CL. Pattern of early human-to-human transmission of Wuhan 2019 novel coronavirus (2019-nCoV), December 2019 to January 2020. Eurosurveillance. (2020) 25:2000058.

5. Chan JF-W, Yuan S, Kok K-H, To KK-W, Chu H, Yang J, et al. A familial cluster of pneumonia associated with the 2019 novel coronavirus indicating person-to-person transmission: a study of a family cluster. Lancet. (2020) 395:514-23.

6. Bailey SC, Wismer GA, Parker RM, Walton SM, Wood AJJ, et al. (2017) Development and rationale for a multifactorial, randomized controlled trial to test strategies to promote adherence to complex drug regimens among older adults. ContempClin Trials. 62: 21-26.

7. 7.Shereen MA, Khan S, Kazmi A, Bashir N, Siddique R. COVID-19 infection: origin, transmission, and characteristics of human coronaviruses. J Adv Res. (2020) 24:91-8. doi: 10.1016/j.jare.2020.03.005

8. Phan LT, Nguyen TV, Luong QC, Nguyen TV, Nguyen HT, Le HQ, et al. Importation and human-to-human transmission of a novel coronavirus in Vietnam. N Engl J Med. (2020) 382:872-4.

9. Parry J. China coronavirus: cases surge as official admits human to human transmission. BMJ. (2020) 368:m236.

10. Li Q, Guan X, Wu P, Wang X, Zhou L, Tong Y, et al. Early transmission dynamics in Wuhan, China, of novel coronavirus-infected pneumonia. N Engl J Med. (2020) 382:1199-207.

11. WHO. Coronaviruses (COVID-19) 2020. Available online at: https://www.who.int/newsroom/q-a-detail/q-a-coronaviruses. 
12. Yang J, Zheng Y, Gou X, Pu K, Chen Z, et al. (2020) Prevalence of comorbidities in the novel Wuhan coronavirus (COVID-19) infection: A systematic review and meta-analysis. Int J Infect Dis. 94: 91-95.

13. Paasche-Orlow MK, Parker RM, Gazmararian JA, Nielsen- Bohlman LT, Rudd RR, et al. (2005) The prevalence of limited health literacy. J Gen Intern Med. 20: 175-84.

14. Wang D, Hu B, Hu C, Zhu F, Liu X, Zhang J, et al. Clinical characteristics of 138 hospitalized patients with 2019 novel coronavirus- infected pneumonia in Wuhan, China. JAMA. (2020) 323:1061-9. doi: 10.1001/jama.2020.1585.

15. Wolf MS, Curtis LM, Wilson EA, Revelle W, Waite KR, et al. (2012) Literacy, cognitive function, and health: results of the LitCog study. J Gen Intern Med. 27: 1300-1307.

16. Weiss BD, Mays MZ, Martz W (2005) Quick assessment of literacy in primary care: The Newest Vital Sign. Ann Fam Med. 3: 514-522.

17. Wolf MS, Smith SG, Pandit AU, Condon DM, Curtis LM, et al. (2018) Development and validation of the Consumer Health Activation Index. Med Decis Making. 38: 334-343.

18. Kelly B, Squiers L, Bann C, Stine A, Hansen H, et al. (2015) Perceptions and plans for prevention of Ebola: Results from a national survey. BMC Public Health. 15: 1136.

19. Lin L, Savoia E, Agboola F, Viswanath K (2014) What have we learned about communication inequalities during the H1N1 pandemic: A systematic review of the literature. BMC Public Health. 14: 484.

20. Rajib Acharya et al., COVID-19-related knowledge, attitudes, and practices among adolescents and young people in Bihar and Uttar Pradesh, India. The Population Council, Inc. (2020):1-6.

21. Dahab, M., van Zandvoort, K., Flasche, S., Warsame, A., Spiegel, P. B., Waldman, J., \& Checchi, F. (2020, March 20). COVID-19 control in low-income settings and displaced populations: What can realistically be done?

22. Wong, G., Liu, W., Liu, Y., Zhou, B., Bi, Y., \& Gao, G. F. (2015). MERS, SARS, and Ebola: The Role of Super-Spreaders in Infectious Disease. Cell Host \& Microbe, 18(4), $398-401$.

23. Vigdor, N. (2020, March 24). Man Fatally Poisons Himself While Self-Medicating for Coronavirus, Doctor Says. The New York Times.

24. Chirwa GC. "Who knows more, and why?" Explaining socioeconomic-related inequality in knowledge about HIV in Malawi. Sci African. (2020) 7:e00213.

25. Chirwa GC. Socio-economic Inequality in Comprehensive Knowledge about HIV in 
Malawi. Malawi Med J. (2019) 31:104-11

26. Podder D, Paul B, Dasgupta A, Bandyopadhyay L, Pal A, Roy S. Community perception and risk reduction practices toward malaria and dengue: a mixed-method study in slums of Chetla, Kolkata. Ind J Public Health. (2019) 63:178.

27. Al-Hanawi M. et al., Knowledge, Attitude and Practice Toward COVID-19 Among the Public in the Kingdom of Saudi Arabia: A Cross-Sectional Study. Front. Public Health. (2020):1-15.

28. CDC. Centers for Disease Control and Prevention: Coronavirus (COVID-19) 2020. Available online at: https://www.cdc.gov/coronavirus/2019-nCoV/index.html (https://www.cdc.gov/coronavirus/2019-nCoV/index.html) (accessed 1 March, 2020).

29. Al-Mohrej OA, Al-Shirian SD, Al-Otaibi SK, Tamim HM, Masuadi EM, Fakhoury HM. Is the Saudi public aware of Middle East respiratory syndrome? J Infect Public Health. (2016) 9:259-66. doi: 10.1016/j.jiph.2015.10.003

30. Aldowyan N, Abdallah AS, El-Gharabawy R. Knowledge, Attitude and Practice (KAP) Study about Middle East Respiratory Syndrome Coronavirus (MERS-CoV) among Population in Saudi Arabia. International Archives of Medicine (2017).doi: 10.3823/2524

31. WHO. WHO, Saudi Arabia join forces to fight COVID-19 nationally, regionally and globally 2020. Available online at: http://www.emro.who.int/media/news/who-saudiarabia-join-forces-to-fight-covid-19-nationally-regionally-and-globally.html (accessed 2 April, 2020).

32. Rugarabamu S, Ibrahim M, Byanaku. A Knowledge, attitudes, and practices (KAP) towards COVID-19: A quick online cross-sectional survey among Tanzanian residents. MedRxiv (2020):1-18. doi: https://doi.org/10.1101/2020.04.26.20080820

33. Blendon RJ, Benson JM, DesRoches CM, Raleigh E, Taylor-Clark K. The public's response to severe acute respiratory syndrome in Toronto and the United States. Clin Infect Dis. (2004) 38:925-31. doi: 10.1086/382355

\section{AJPHR is}

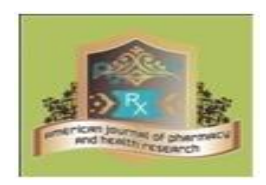

Peer-reviewed

monthly

Rapid publication

Submit your next manuscript at

editor@ajphr.com / editor.ajphr@gmail.com 